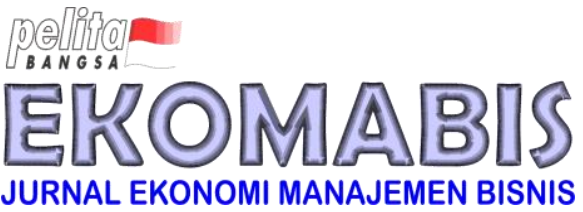

\title{
Pengaruh Pelatihan, Lingkungan, dan Kepuasan Kerja Terhadap Kinerja Karyawan PT. Mandom Indonesia Tbk
}

(The Influence of Job Training, Work Environment, and Job Satisfaction on The Performance of Employees of PT. Mandom Indonesia Tbk)

\section{Yuli Triastuti ${ }^{1}$; Dina Wulandari²; Susilowati Budiningsih ${ }^{3}$; Koentari ${ }^{4}$}

\begin{abstract}
Abstrak
Penelitian ini ditujukan guna menguji pengaruh pelatihan, lingkungan, kepuasan kerja terhadap kinerja karyawan pada PT Mandom Indonesia Tbk. Sampel penelitian ini mencakup 90 karyawan PT Mandom Indonesia Tbk. Hasil analisis regresi linier berganda menemukan bahwa variable pelatihan dan lingkungan kerja berpengaruh positif terhadap kinerja karyawan. Namun demikian, kepuasan kerja tidak berpengaruh signifikan terhadap kinerja karyawan. Penelitian ini menunjukkan bahwa pelatihan kerja dan lingkungan kerja memiliki pengaruh yang sama besarnya terhadap kinerja karyawan. Kebijakan perusahaan pada peningkatan pelatihan dan penciptaan lingkungan kerja yang baik secara berkelanjutan perlu dilakukan dalam rangka mempertahankan kualitas dan meningkatkan kinerja karyawan.

Kata Kunci: Kepuasan Kerja, Kinerja, Lingkungan Kerja, Pelatihan
\end{abstract}

\begin{abstract}
This study is intended to examine the effect of training, work environment, job satisfaction on employee performance at PT Mandom Indonesia Tbk. The sample of this research includes 90 employees of PT Mandom Indonesia Tbk. The analysis found that the variables of job training and work environment had a positive effect on employee performance. However, job satisfaction has no significant effect on employee performance. This study shows that job training and work environment have the same effect on employee performance. Company policies on improving training and creating a good work environment on an ongoing basis need to be carried out in order to maintain quality and improve employee performance. Keywords: Job Satisfaction, Performance, Training, Work Environment
\end{abstract}

1 "Sekolah Tinggi Ilmu Ekonomi IPWI Jakarta"; yulitrias@gmail.com

2 "Sekolah Tinggi Ilmu Ekonomi IPWI Jakarta"; dina.wulandari.1207@gmail.com

3 "Sekolah Tinggi Ilmu Ekonomi IPWI Jakarta"; susilowatisubud@gmail.com

4 "Sekolah Tinggi Ilmu Ekonomi IPWI Jakarta"; almamita45@gmail.com 


\section{Pendahuluan}

Perusahaan membutuhkan sumber daya manusia sebagai penggerak jalannya operasional perusahaan. Bagi perusahaan, keberadaan sumber daya manusia membantu perusahaan bertahan dan berkembang di dalam industri. Perusahaan yang dapat bertahan di dalam suatu industri dan mampu menghasilkan keuntungan adalah perusahaan yang mampu menyesuaikan kegiatan bisnisnya dengan perkembangan di masyarakat. Pengaruh perkembangan yang terjadi di masyarakat akan berpengaruh terhadap kondisi sumber daya manusia yaitu karyawan. Di sisi lain, kondisi sumber daya manusia perusahaan juga secara langsung dipengaruhi oleh keadaan internal perusahaan. Pengaruh lingkungan eksternal dan internal perusahaan akan membawa dampak terhadap kinerja karyawan dan berpengaruh terhadap kondisi perusahaan secara umum. Kinerja karyawan pada dasarnya merupakan bagian penting perusahaan karena berhubungan dengan aset perusahaan. Kualitas karyawan yang membantu perusahaan mencapai tujuan utamanya (Citraningtyas \& Djastuti, 2017).

Sumber daya manusia menjadi faktor penting keberhasilan perusahaan mewujudkan tujuannya. Sumber daya manusia memegang peranan sebagai penggerak utama di sebuah perusahaan. Sumber daya manusia menjadi penentu kelayakan di dalam suatu perusahaan yang berperan dalam proses penetapan rencana, proses, sistem, dan tujuan yang ingin dicapai (Hasibuan, 2006). Sumber daya manusia berperan sebagai rekan kerja pengusaha dalam mencapai keberhasilan perusahaan. Karyawan harus dikelola dengan baik dan mendapat perhatian agar mampu bekerja produktif dan berkontribusi optimal bagi perusahaan (Daspar, 2020). Keberhasilan pengelolaan sumber daya manusia tidak terlepas dari pengaruh lingkungan perusahaan. Lingkungan kerja yang baik dapat membawa efek positif pada kinerja karyawan (Berliana, Susijawati, \& Sulistyowati, 2020). Pada sisi lain, lingkungan kerja nyatanya dapat juga berpengaruh negatif terhadap kinerja pegawai (Safira \& Rozak, 2020).

Kondisi penurunan sumber daya manusia juga pernah dialami oleh produsen kosmetika, bahan pembersih, dan kemasan plastik PT. Mandom Indonesia Tbk. Tahun 2016, jumlah karyawan PT. Mandom Indonesia Tbk mengalami penurunan dibanding tahun 2015. Penurunan ini disebabkan banyak karyawan yang menarik diri dan berpindah ke perusahaan lain dengan alasan lingkungan kerja yang dianggap kurang memadai sehingga karyawan tidak nyaman dalam bekerja. Jam kerja yang tinggi menjadi salah satu alasan karyawan mengundurkan diri. Berkaca dari kondisi tersebut dan seiring berkembangnya pengetahuan dalam pengelolaan manajemen, PT. Mandom Indonesia Tbk kemudian melakukan berbagai perubahan manajemen. Ketersediaan alat dan mesin juga diperbaharui dengan kualitas yang lebih baik. Hal ini diharapkan akan mendukung kepuasan kerja karyawan. Kepuasan dapat dijelaskan sebagai perasaan yang muncul atas penerimaan hasil dibandingkan dengan ekspektasi yang diinginkannya (Primadhita \& Budiningsih, 2019). Semakin tinggi kepuasan kerja karyawan akan dapat meningkatkan kinerja karyawannya (Arda, 2017). Namun terdapat juga kondisi kepuasan kerja nyatanya tidak membawa pengaruh terhadap kinerja karyawannya (Adiyasa \& Windayanti, 2019).

Selain lingkungan kerja, pencapaian kinerja sesuai yang diharapkan perusahaan dipengaruhi juga oleh berbagai faktor, salah satunya penguasaan terhadap bidang pekerjaan. Penguasaan kerja karyawan ini berkaitan erat dengan pelatihan yang diberikan kepada karyawan. Pelatihan diselenggarakan sebagai upaya menaikkan kinerja karyawan di masa kini atau pekerjaan lain yang menjadi tanggungjawabnya di 
masa mendatang (Sutrisno, 2016). Semakin besar pelatihan yang diberikan kepada karyawan dapat berdampak pada semakin kompetennya karyawan dan memiliki kinerja yang lebih baik (Simaremare \& Isyandi, 2015). Ini terjadi karena pelatihan berkaitan erat dengan upaya untuk meningkatkan keahlian pegawai agar prestasi kerja karyawan dapat meningkat. Namun demikian, pelatihan dapat menjadi tidak berpengaruh signifikan terhadap kinerja karyawan jika metode pelatihan yang diberikan tidak sesuai dengan materi yang diberikan (Ningsi, Alhabsji, \& Utami, 2015).

Belum ada titik temu penelitian dimana pelatihan berdampak pada kinerja yang lebih baik (Simaremare \& Isyandi, 2015) sementara yang lain menemukan bahwa pelatihan dapat menjadi tidak berpengaruh terhadap kinerja (Ningsi, Alhabsji, \& Utami, 2015). Lingkungan kerja ada yang mempengaruhi (Berliana, Susijawati, \& Sulistyowati, 2020) dan adapula yang tidak mempengaruhi (Safira \& Rozak, 2020) kinerja pegawai. Kepuasan kerja meningkatkan kinerja karyawan (Arda, 2017) sedangkan penelitian lain mengungkap bahwa kepuasan nyatanya tidak membawa pengaruh (Adiyasa \& Windayanti, 2019). Berawal dari kesenjangan ini maka penelitian akan mengungkap kembali menjadi sebuah model. Hal ini dilakukan mengingat permasalahan tersebut terjadi di PT. Mandom Indonesia Tbk dan merupakan hal penting dalam meraih apa yang diingankan perusahaan.

Keberhasilan perusahaan tidak terlepas dari peran serta karyawan. Karyawan yang menunjukkan kinerja yang baik akan memberikan efek baik bagi perusahaan. Kinerja karyawan semakin baik akan menghasilkan peningkatan produktifitas perusahaan dan membantu perusahaan untuk dapat tumbuh di dalam industri dan memiliki daya saing. Oleh karenanya, pengukuran kinerja menjadi hal utama yang harus dilakukan dan dievaluasi secara berkala. Penelitian ini menjadi penting dilakukan sebagai bagian dari evaluasi dan penyusunan strategi pengelolaan bidang sumber daya manusia PT. Mandom Indonesia Tbk yang mendukung terciptanya kinerja karyawannya yang lebih tinggi lagi. Pengalaman dalam hal penurunan karyawan telah membuat perusahaan ini mengevaluasi berbagai kebijakan dalam manajemennya. Efektivitas perbaikan pengelolaan sumber daya manusia yang telah dilakukan perusahaan diteliti dengan melihat keterkaitan pelatihan, lingkungan, dan kepuasan pada kinerja di PT. Mandom Indonesia Tbk.

\section{Metodologi}

\subsection{Pengembangan Konsep}

Pelatihan kerja yang diberikan kepada karyawan akan memberikan tambahan ilmu dan meningkatkan kompetensi karyawannya. Materi pelatihan yang disesuaikan dengan bidang kerja karyawan akan mendukung karyawan meningkatkan keahliannya di bidang tersebut. Peningkatan ini dapat membawa perbaikan pada produktivitas karyawannya dan akan meningkatkan kinerja karyawan (Simaremare \& Isyandi, 2015; Citraningtyas \& Djastuti, 2017; Berliana, Susijawati, \& Sulistyowati, 2020). Berkenaan dengan hal tersebut maka hipotesis yang dapat disusun adalah pelatihan kerja diduga berpengaruh positif terhadap kinerja karyawan. Sehingga dapat disusun hipotesis sebagai berikut:

\section{H1: Pelatihan kerja berpengaruh positif terhadap kinerja}


Lingkungan kerja yang kondusif dan baik akan membawa kenyamanan kerja bagi karyawan. Lingkungan kerja yang semakin dianggap baik, akan memberi dampak pada semakin besarnya rasa nyaman dan kondisi kondusif bagi karyawan untuk melaksanakan aktivitas pekerjaannya. Lingkungan kerja yang baik di tempat kerja akan menyebabkan karyawan fokus berkerja dan ini akan membawa dampak baik bagi kinerja karyawan (Citraningtyas \& Djastuti, 2017; Daspar, 2020). Dengan demikian, dapat dikatakan bahwa lingkungan diduga berpengaruh positif pada kinerja. Sehingga dapat disusun hipotesis sebagai berikut:

H2: Lingkungan kerja berpengaruh positif terhadap kinerja

Ketenangan karyawan dalam bekerja dapat tercipta jika karyawan puas dengan apa yang diterimanya, sebagai contoh terkait dengan besaran gaji, kejelasan karir, dan kecocokan dengan rekan kerja. Karyawan yang merasa puas dengan yang diterimanya maka akan menimbulkan ketenangan dalam bekerja (Arda, 2017). Kepuasan akan menciptakan meningkatnya kerelaan dalam bekerja dan hal ini akan dapat meningkatkan kinerja karyawan untuk bisa berkarya lebih baik lagi. Kepuasan kerja dapat diduga sementara berpengaruh positif kepada kinerja karyawan. Sehingga dapat disusun hipotesis sebagai berikut:

H3: Kepuasan kerja erpengaruh positif terhadap kinerja

Tabel 1. Operasionalisasi Variabel

\begin{tabular}{llll}
\hline \multicolumn{1}{c}{ Variabel/ Konsep } & & \multicolumn{1}{c}{ Indikator } & Skala \\
\hline Pelatihan Kerja (Simaremare \& & - & Instruksi & $1-5$ \\
Isyandi, 2015) & - & Peserta & \\
& - & Materi & \\
& - & Metode & \\
\hline Lingkungan Kerja & - & Tujuan & $1-5$ \\
(Citraningtyas \& Djastuti, 2017) & - & Penerangan & \\
& - & Suhu udara & \\
& - & Bau tidak sedap & $1-5$ \\
\hline Kepuasan Kerja (Arda, 2017) & - & Dekorasi & \\
& - & Pekerjaan & \\
& - & Gaji & \\
\hline Kinerja Karyawan & - & Promosi & $1-5$ \\
(Citraningtyas \& Djastuti, 2017) & - & Pengawasan & \\
& - & Rekan Kerja & \\
& - & Tepat & \\
& - & Konsisten & \\
& - & Denantang & \\
& - & Disepakati & \\
& - & Dapat dicapai & \\
\hline
\end{tabular}

Sumber: Rangkuman teori, 2021 
Gambar 1. Model Penelitian

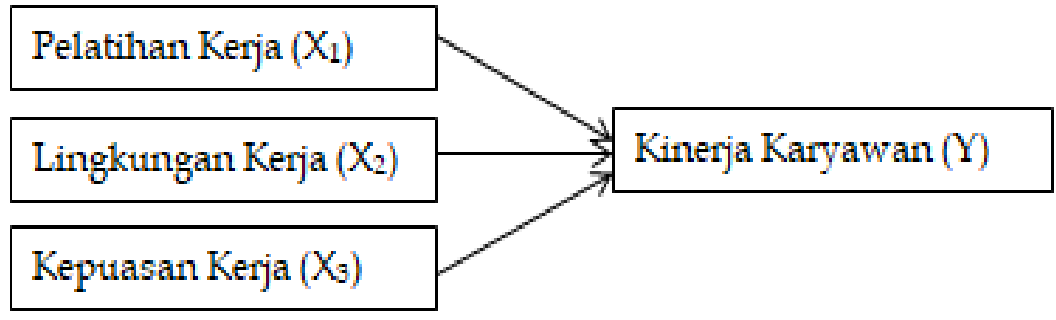

Sumber: Olahan penulis, 2021

\subsection{Pengumpulan Data}

Penelitian dilaksanakan dengan menggunakan data primer. Pengumpulan data dan informasi dilakukan pada bulan November 2019-Januari 2021 melalui pengamatan langsung pada objek. Data diperoleh dengan teknik pengamatan, wawancara, dan penyebaran kuesioner terhadap 90 sampel penelitian yaitu karyawan PT. Mandom Indonesia Tbk. Kuesioner yang dibagikan kepada responden memakai skala Likert yang dikembangkan dari indikator penelitian.

\subsection{Metode Analisis}

Analisis pada data kuesioner diawali dengan uji validitas dan reliablitas. Uji reliabilitas menggunakan angka cronbach alpha yang dibandingkan dengan ketentuan minimal nilai cronbach alpha yaitu 0,6. Data reliabel jika cronbach alpha lebih dari 0,6 dan sebaliknya data tidak reliabel jika cronbach alpha kurang dari 0,6. Untuk uji validitas dilakukan dengan membandingkan nilai r-hitung pada hasil corrected item-total correlation dengan kriteria data valid jika r-hitung lebih dari r-tabel atau r-hitung lebih dari 0,207 dan data tidak valid jika r-hitung kurang dari r-tabel atau r-hitung kurang dari 0,207.

Selanjutnya, analisis didahului dengan uji persyaratan analisis analisis yang disebut uji asumsi klasik, linier dan hipotesis. Uji asumsi sebagai persyaratan terdiri atas uji normalitas dan autokorelasi. Uji normalitas memakai uji Kolmogorov Smirnov. Sedangkan uji autokorelasi yaitu bukti tidak adanya kesalahan kecil dengan Durbin Watson. Selanjutnya dilakukan uji regresi linier ganda. Nilai yang digunakan adalah koefisien regresi dari variabel independen pertama $\left(X_{1}\right)$ Pelatihan Kerja dengan simbol $b_{1}$, variabel kedua $\left(X_{2}\right)$ Lingkungan Kerja dengan simbol $b_{2}$, dan variabel ketiga $\left(X_{3}\right)$ Kepuasan Kerja dengan simbol $b_{3}$ terhadap satu variabel dependen Kinerja karyawan $(\mathrm{Y})$.

$Y=a+b_{1} X_{1}+b_{2} X_{2}+b_{3} X_{3}$

Langkah terakhir adalah pengujian hipotesis dengan menggunakan nilai koefisien determinasi atau $R$ Square $\left(R^{2}\right)$, uji parsial (t) dan uji simultan (f). Layak atau tidaknya model penelitian terlihat dari besaran nilai $\mathrm{R}$ Square dan uji $\mathrm{F}$, yaitu dengan melihat nilai probabilitas (Sig F) dibandingkan taraf uji penelitian $(\alpha=0,05)$. Analisis bisa dilanjutkan jika $\mathrm{R}^{2}$ mendekati atau lebih dari 50\% dan nilai Sig F kurang dari 0,05. Hipotesis penelitian menggunakan tingkat presisi $(\alpha)=5 \%=0,05$ yang dilakukan terhadap masing-masing hipotesis variabel. 
Tabel 2. Uji Validitas dan Reliabilitas

\begin{tabular}{|c|c|c|c|}
\hline Variabel/Indikator & Correlation & Cronbach Alpha & Kesimpulan \\
\hline Pelatihan Kerja & & 0,897 & Reliabel \\
\hline - Persiapan materi & 0,621 & 0,888 & Valid \\
\hline - Pendidikan pemateri & 0,840 & 0,871 & Valid \\
\hline - Menjalankan perintah & 0,798 & 0,876 & Valid \\
\hline - Menjalankan pekerjaan & 0,614 & 0,889 & Valid \\
\hline - Sasaran jelas & 0,497 & 0,896 & Valid \\
\hline - Pemahaman & 0,489 & 0,896 & Valid \\
\hline - Peningkatan keterampilan & 0,499 & 0,895 & Valid \\
\hline - Produksi meningkat & 0,425 & 0,900 & Valid \\
\hline - $\quad$ Mendorong aplikasi materi & 0,840 & 0,871 & Valid \\
\hline - Mempraktekan materi & 0,798 & 0,876 & Valid \\
\hline Lingkungan Kerja & & 0,975 & Reliabel \\
\hline - Fasilitas kerja & 0,866 & 0,972 & Valid \\
\hline - Tempat menyehatkan & 0,894 & 0,971 & Valid \\
\hline - Saling menghormati & 0,887 & 0,971 & Valid \\
\hline - Harmonis & 0,868 & 0,972 & Valid \\
\hline - $\quad$ Fasilitas kantin & 0,866 & 0,972 & Valid \\
\hline - $\quad$ Fasilitas mushola & 0,894 & 0,971 & Valid \\
\hline - Pencahayaan & 0,887 & 0,971 & Valid \\
\hline - Penerangan & 0,868 & 0,972 & Valid \\
\hline - Kondisi udara & 0,866 & 0,972 & Valid \\
\hline - Ventilasi udara & 0,894 & 0,971 & Valid \\
\hline Kepuasan Kerja & & 0,662 & Reliabel \\
\hline - Dukungan pimpinan & 0,286 & 0,804 & Valid \\
\hline - $\quad$ Briefing pagi & 0,704 & 0,539 & Valid \\
\hline - Gaji sesuai beban kerja & 0,534 & 0,588 & Valid \\
\hline - Gaji sesuai UMR & 0,704 & 0,539 & Valid \\
\hline - Promosi karir & 0,335 & 0,637 & Valid \\
\hline - $\quad$ Keamanan kerja & 0,704 & 0,539 & Valid \\
\hline - $\quad$ Pekerjaan sesuai & 0,284 & 0,667 & Valid \\
\hline kemampuan & 0,281 & 0,649 & Valid \\
\hline Rekan saling membantu & & & \\
\hline Kinerja Karyawan & & 0,765 & Reliabel \\
\hline - Bekerja cepat & 0,541 & 0,729 & Valid \\
\hline - Kualitas lebih baik & 0,491 & 0,736 & Valid \\
\hline - Sesuai target & 0,487 & 0,736 & Valid \\
\hline - $\quad$ Lebih efektif dan teliti & 0,545 & 0,729 & Valid \\
\hline - Ingin belajar hal baru & 0,311 & 0,762 & Valid \\
\hline - Bekerja dengan baik & 0,431 & 0,745 & Valid \\
\hline - Komitmen mencapai target & 0,498 & 0,735 & Valid \\
\hline - Pencapaian target & 0,487 & 0,736 & Valid \\
\hline - Sesuai jobdes dan prosedur & 0,248 & 0,776 & Valid \\
\hline
\end{tabular}

Sumber: Data penelitian yang telah diolah, 2021 


\section{Hasil}

Berdasarkan hasil pengumpulan data diketahui bahwa 90 responden terdiri atas 68 orang pria dan 22 wanita. Responden yang berumur 18-25 tahun sebanyak 15,6\%, 25-30 tahun sebanyak $44,4 \%, 30-35$ tahun sebanyak $36,7 \%$, sedangkan umur lebih dari 35 tahun sebanyak 3.3\%. Sebagian besar responde berpendidikan SMA/sederajat yaitu 43\%, Diploma/S1 sebesar 38\%, SMP sebesar 14\%, dan lainnya sebesar 3\%.

Selanjutnya, hasil pengolahan data diuji dengan menggunakan uji validitas indikator dan uji reliabilitas variabel. Uji validitas memperlihatkan hasil bahwa 10 butir indikator pernyataan variabel pelatihan kerja dikatakan valid karena masing-masing butir memiliki r-hitung lebih dari 0,207. Pada variabel kedua, uji validitas terhadap 10 butir indikator variabel lingkungan kerja dikatakan valid. Sementara untuk variabel kepuasan kerja, hasil pengujian memperlihatkan 8 butir indikator pernyataan juga dinyatakan valid. Pada variabel kinerja karyawan, terdapat 9 butir indikator yang dapat dinyatakan valid.

Secara keseluruhan sebagaimana tabel 2 terlihat bahwa data penelitian dari kuesioner untuk pelatihan kerja 10 valid, lingkungan kerja 10 valid, kepuasan kerja 8 valid, dan kinerja karyawan 9 valid. Seluruh variabel penelitian dinyatakan reliabel karena memiliki nilai cronbach alpha lebih dari 0,6. Oleh karenanya, dapat diambil kesimpulan bahwa seluruh instrumen pada penelitian ini dapat dipakai untuk analisis.

Persyaratan analisis melalui uji asumsi telah terpenuhi. Hasil uji normalitas yaitu berdasarkan One Sample Kolmogorov-Smirnov Test membandingkan nilai probabilitas terhadap a menunjukkan nilai sig 0,815 lebih besar dari 0,05. Autokorelasi terpenuhi karena nilai Durbin-Watson 2.262.

Uji kelayakan model (Tabel 3) memperlihatkan model pelatihan, lingkungan dan kepuasan pada kinerja karyawan menghasilkan nilai koefisien determinasi ganda Adjusted $R$ Square dengan nilai 0.503. Hasil pengujian memperlihatkan model penelitian dapat diterima dan layak karena mampu menjelaskan $50.3 \%$ variasi pelatihan, lingkungan dan kepuasan terhadap kinerja, sedangkan 49.7\% variasi Y lainnya dapat dijelaskan dengan variabel lain di luar variabel penelitian.

Hasil analisis pada pengujian hipotesis pelatihan, lingkungan dan kepuasan terhadap kinerja, diperoleh nilai F sebesar 31.019 dan Sig. sebesar 0.000 (Tabel 3). Nilai sig. kurang dari 0,05 dapat diartikan bahwa Ho ditolak, sehingga dapat diambil keputusan bahwa model yang diajukan layak untuk mengiji hipotesis.

Tabel 3. Koefisien Determinasi

\begin{tabular}{ccccc}
\hline $\mathrm{R}^{2}$ & Adj. R & F-stat & Prob (F-stat) & DW \\
\hline 0,520 & 0,503 & 31,019 & 0,000 & 2,262 \\
\hline
\end{tabular}

Sumber: Data penelitian yang diolah, 2021

Hasil analisis (tabel 4) memperlihatkan pengaruh parsial pelatihan kerja $\left(\mathrm{X}_{1}\right)$, lingkungan kerja $\left(\mathrm{X}_{2}\right)$ dan kepuasan kerja $\left(\mathrm{X}_{3}\right)$ terhadap kinerja karyawan $(\mathrm{Y})$. Model persamaan regresi linier ganda menghasilkan: $Y=12,499+0,230 X 1+0,230 X 2+0,217 X 3$. 1) Nilai konstanta $a=12.499$, yang menandakan jika $X_{1}, X_{2}$, dan $X_{3}$ bernilai konstan maka $Y$ akan memiliki nilai positif; 2) Nilai koefisien $X_{1}=0.230$ dengan nilai probabilitas $t-$ 
hitung sebesar 0.001 menandakan $\mathrm{X}_{1}$ berpengaruh signifikan dengan arah positif terhadap $Y$;3) Nilai koefisien regresi $X_{2}=0.230$ dengan nilai probabilitas t-hitung sebesar 0.002 memperlihatkan $X_{2}$ berpengaruh signifikan dengan arah positif terhadap $Y ; 4$ ) Nilai koefisien regresi $X_{3}=0.217$ dengan nilai probabilitas t-hitung sebesar 0.200 menunjukkan bahwa $\mathrm{X}_{3}$ tidak berpengaruh signifikan terhadap $\mathrm{Y}$.

Tabel 4. Hasil Uji Analisis

\begin{tabular}{lccccc}
\hline \multicolumn{1}{c}{ Variabel } & Koefisien & Std. Error & $\mathrm{T}$ & Sig. & Keputusan \\
\hline Constant & 12,499 & 3,459 & 3,613 & 0,001 & \\
Pelatihan & 0,230 & 0,066 & 3,478 & 0,001 & H1 diterima \\
Lingkungan Kerja & 0,230 & 0,074 & 3,122 & 0,002 & H2 diterima \\
Kepuasan Kerja & 0,217 & 0,168 & 1,291 & 0,200 & H3 ditolak \\
\hline
\end{tabular}

Sumber: Data yang diolah, 2021

\section{Pembahasan}

\subsection{Pengaruh Pelatihan Kerja terhadap Kinerja Karyawan}

Pelatihan mempunyai pengaruh parsial yang signifikan positif pada kinerja. Hal ini berarti semakin tinggi pelatihan akan meningkatkan kinerja karyawan. Besarnya pengaruh pelatihan terhadap kinerja ditunjukan oleh nilai koefisien sebesar 0.230 pada model persamaan regresi linier. Hasil penelitian ini mendukung penelitian (Simaremare \& Isyandi, 2015; Citraningtyas \& Djastuti, 2017; Berliana, Susijawati, \& Sulistyowati, 2020) yang memperlihatkan bahwa pelatihan berpengaruh positif dan signifikan pada kinerja. Kondisi ini memperlihatkan bahwa faktor pelatihan kerja penting dalam meningkatkan kinerja karyawan. Dengan adanya pelatihan, maka kompetensi dan keahlian yang dimiliki karyawan akan meningkat dan ini akan menyebabkan karyawan semakin menguasai bidang pekerjaannya.

Peningkatan kapabilitas karyawan ini tentunya akan dapat membawa dampak baik pada kualitas kerja karyawan dan pada akhirnya meningkatkan kinerjanya. Dalam hal ini, perusahaan juga harus memperhatikan kualitas instruktur, metode pelatihan, tujuan pelatihan, dan materi pelatihan karena akan berpengaruh terhadap peningkatan kinerja karyawan. Kedalaman materi dan penyampaian instruktur pelatihan membawa dampak bagi berhasil atau tidaknya pelatihan kerja. Pelatihan kerja juga diarahkan pada kesesuaian kebutuhan karyawan yang menjadi peserta pelatihan sehingga pada akhirnya materi yang diberikan akan mampu mendorong karyawan untuk mengaplikasikan materi yang telah diterimanya dalam melaksanakan pekerjaannya agar lebih berinovasi setelah mengikuti pelatihan. Dengan demikian pelatihan akan membawa pada peningkatan kinerja.

\subsection{Pengaruh Lingkungan Kerja terhadap Kinerja Karyawan}

Lingkungan kerja berpengaruh parsial positif signifikan pada kinerja yang menandakan semakin tingginya lingkungan kerja akan meningkatkan kinerja. Pengaruh lingkungan kerja pada kinerja ditunjukan dari nilai koefisien sebesar 0.230 . Hasil penelitian ini 
sejalan dengan penelitian lain (Citraningtyas \& Djastuti, 2017; Daspar, 2020) yang membuktikan bahwa terdapat pengaruh positif signifikan lingkungan kerja pada kinerja. Semakin tinggi nilai lingkungan kerja menunjukkan lingkungan yang semakin baik. Lingkungan kerja yang dinilai baik oleh karyawan akan menciptakan rasa nyaman dan memunculkan keinginan terus bekerja dan bertahan di perusahaan. Kondisi ini akan menyebabkan meningkatnya kinerja para karyawan.

Perusahaan harus berupaya untuk menciptakan suasana kerja yang menyenangkan dengan fasilitas pekerjaan yang lengkap dan memadai sehingga mendukung karyawan melaksanakan pekerjaannya. Hubungan dengan rekan kerja yang saling menghormati dan harmonis juga mendukung terciptanya lingkungan kerja yang baik dan membawa ketenangan dan kenyamanan dalam bekerja. Lingkungan kerja yang baik juga identik dengan tersedianya kantin dan mushola bagi para karyawannya, sehingga ketika dibutuhkan karyawan akan dengan mudah mengaksesnya. Kemudahan ini akan mengefisienkan waktu kerja karyawan sehingga dapat bekerja tepat waktu. Perusahaan juga harus memperhatikan kondisi ruang kerja dengan penerangan dan sirkulasi udara yang baik karena hal ini akan mempengaruhi kesehatan karyawan dan menjadi faktor penentu baik atau buruknya lingkungan kerja. Jika kesemua faktor ini dapat disediakan dengan kualitas yang baik maka tentunya akan mendukung semangat karyawan untuk berkerja dan berkinerja baik.

\subsection{Pengaruh Kepuasan Kerja terhadap Kinerja Karyawan}

Kepuasan kerja pada penelitian ini tidak memiliki pengaruh yang signifikan terhadap kinerja karyawan. Hasil penelitian ini sejalan dengan penelitian lain (Adiyasa \& Windayanti, 2019) yang menemukan bahwa kepuasan kerja tidak mempengaruhi kinerja secara signifikan. Hasil ini tidak sejalan dengan penelitian lainnya lagi (Arda, 2017) yang menemukan kepuasan kerja berdampak positif dan signifikan pada kinerja karyawan. Tidak signifikannya hasil penelitian ini dapat terjadi mengingat hubungan antara kepuasan kerja dengan kinerja masih menjadi hal yang diperdebatkan (Robbins \& Judge, 2016), walaupun banyak penelitian membuktikan bahwa karyawan yang puas akan memberikan efek pada kinerja yang lebih tinggi. Dengan penemuan ini, implikasi perusahaan jika ingin meningkatkan kinerja karyawan maka harus lebih berfokus pada lingkungan kerja dan pelatihan kerja.

\section{Kesimpulan}

Pelatihan memiliki pengaruh positif pada kinerja karyawan pada PT. Mandom Indonesia Tbk. Lingkungan kerja memiliki pengaruh signifikan positif pada kinerja karyawan pada PT. Mandom Indonesia Tbk yang artinya lingkungan kerja yang semakin baik, akan meningkatkan kinerja karyawan. Kepuasan kerja tidak berpengaruh secara signifikan pada kinerja karyawan pada PT. Mandom Indonesia Tbk.

Manajemen dapat menerapkan berbagai kebijakan antara lain meningkatkan pelatihan bagi para karyawannya dan tetap melakukan inovasi agar lingkungan kerja yang tercipta semakin menyenangkan bagi karyawan. Kebijakan yang selama ini telah berjalan dalam hal melakukan perubahan dan perbaikan pada aspek sumber daya manusia yang harus tetap dilakukan secara berkelanjutan dalam rangka mempertahankan kualitas dan meningkatkan kinerja karyawan. 


\section{Daftar Pustaka}

Adiyasa, N., \& Windayanti. (2019). Pengaruh Motivasi, Kepuasan Kerja, dan Kepemimpinan Terhadap Kinerja Karyawan Pada PT. XYZ. Jurnal Manajemen Strategi dan Aplikasi Bisnis, 2(1), 23-30.

Arda, M. (2017). Pengaruh Kepuasan Kerja dan Disiplin Kerja Terhadap Kinerja Karyawan pada Bank Rakyat Indonesia Cabang Putri Hijau Medan. Jurnal ilmiah Manajemen dan Bisnis, 18(1), 45-60.

Berliana, V., Susijawati, N., \& Sulistyowati, L. (2020). Pengaruh Pelatihan dan Lingkungan Kerja Terhadap Kinerja Karyawan. Jurnal Manajemen, 12(2), 280-287.

Citraningtyas, N., \& Djastuti, I. (2017). Pengaruh Pelatihan dan Lingkungan Kerja Terhadap Kinerja Karyawan dengan Kepuasan Kerja Sebagai Variabel Intervening (Studi Pada Karyawan Hotel Megaland Solo). Diponegoro Journal of Management, 6(4), 1-11.

Daspar, D. (2020). Pengaruh Lingkungan, Motivasi dan Disiplin Kerja Terhadap Kinerja Karyawan: (The Influence of Work Environment, Motivation and Work Discipline Toward Employee Performance). EKOMABIS: Jurnal Ekonomi Manajemen Bisnis, 1(2), 159-166.

Hasibuan, M. (2006). Manajemen Sumber Daya Manusia, Edisi Revisi. Jakarta: PT. Bumi Aksara.

Ningsi, C., Alhabsji, T., \& Utami, H. (2015). Pengaruh Pelatihan dan Promosi Terhadap Motivasi dan Kinerja Karyawan. Jurnal Administrasi Publik, 5(1), 131-143.

Primadhita, Y., \& Budiningsih, S. (2019). Pengaruh Kualitas Layanan dan Produk Terhadap Kepuasan Nasabah Bank Syariah. 16(2), 121-130.

Robbins, S., \& Judge, T. (2016). Perilaku Organisasi, Edisi 16. Jakarta: Salemba Empat.

Safira, A., \& Rozak, H. (2020). Pengaruh Budaya Organisasi, Lingkungan Kerja, dan Kompetensi Terhadap Kinerja Pegawai (Studi Pada Perum Perhutani Divisi Regional Jawa Tengah). Proceeding SENDIU (pp. 519-523). Semarang: Universitas Stikubank.

Saputra, A., Bagia, I., \& Yulianthini, N. (2016). Pengaruh Kepuasan Kerja dan Loyalitas Karyawan Terhadap Kinerja Karyawan. Jurnal Manajemen, 4, 1-8.

Simaremare, C., \& Isyandi, H. (2015). Pengaruh Pelatihan, Lingkungan Kerja Fisik, dan Kepemimpinan Terhadap Kepuasan Kerja dalam Meningkatkan Kinerja Karyawan pada PT. Federal International Finance Wilayah Riau. Jurnal Tepak Manajemen Bisnis, 7(3), 377-387.

Sugiyono. (2016). Metode Penelitian Kuantitatif, Kualitatif, and RED. Bandung: PT. Alfabeta.

Sutrisno, E. (2016). Manajemen Sumber Daya Manusia, Cetakan ke-8. Jakarta: Prenada Media Grup. 